1. Extended Data

\begin{tabular}{|c|c|c|c|}
\hline Figure \# & $\begin{array}{l}\text { Figure title } \\
\text { One sentence } \\
\text { only }\end{array}$ & $\begin{array}{l}\text { Filename } \\
\text { This should be } \\
\text { the name the } \\
\text { file is saved as } \\
\text { when it is } \\
\text { uploaded to our } \\
\text { system. Please } \\
\text { include the file } \\
\text { extension. i.e.: } \\
\text { Smith_ED_Fi_1.j } \\
\text { pg }\end{array}$ & $\begin{array}{l}\text { Figure Legend } \\
\text { If you are citing a reference for the first time } \\
\text { in these legends, please include all new } \\
\text { references in the Online Methods References } \\
\text { section, and carry on the numbering from the } \\
\text { main References section of the paper. }\end{array}$ \\
\hline $\begin{array}{l}\text { Extended } \\
\text { Data Fig. } 1\end{array}$ & & & \\
\hline $\begin{array}{l}\text { Extended } \\
\text { Data Fig. } 2\end{array}$ & & & \\
\hline $\begin{array}{l}\text { Extended } \\
\text { Data Fig. } 3\end{array}$ & & & \\
\hline $\begin{array}{l}\text { Extended } \\
\text { Data Fig. } 4\end{array}$ & & & \\
\hline $\begin{array}{l}\text { Extended } \\
\text { Data Fig. } 5 \\
\end{array}$ & & & \\
\hline $\begin{array}{l}\text { Extended } \\
\text { Data Fig. } 6\end{array}$ & & & \\
\hline $\begin{array}{l}\text { Extended } \\
\text { Data Fig. } 7\end{array}$ & & & \\
\hline $\begin{array}{l}\text { Extended } \\
\text { Data Fig. } 8\end{array}$ & & & \\
\hline $\begin{array}{l}\text { Extended } \\
\text { Data Fig. } 9\end{array}$ & & & \\
\hline $\begin{array}{l}\text { Extended } \\
\text { Data Fig. } 10\end{array}$ & & & \\
\hline
\end{tabular}

3 2. Supplementary Information:

4 A. Flat Files

5

\begin{tabular}{|l|l|l|l|}
\hline Item & Present? & $\begin{array}{l}\text { Filename } \\
\text { This should be } \\
\text { the name the file } \\
\text { is saved as when } \\
\text { it is uploaded to } \\
\text { our system, and } \\
\text { should include } \\
\text { the file extension. } \\
\text { The extension } \\
\text { must be.pdf }\end{array}$ & $\begin{array}{l}\text { A brief, numerical description of } \\
\text { file contents. } \\
\text { i.e.: Supplementary Figures 1-4, } \\
\text { Supplementary Discussion, and } \\
\text { Supplementary Tables 1-4. }\end{array}$ \\
& & $\begin{array}{l}\text { 17006_3_sup } \\
\text { p_168761_q1 } \\
\text { mrh5_convrt. }\end{array}$ & $\begin{array}{l}\text { i.e.: Evaluation of halogens } \\
\text { abundances and distributions in } \\
\text { CAM-Chem, Supplementary }\end{array}$ \\
\hline Supplementary & Yes & &
\end{tabular}




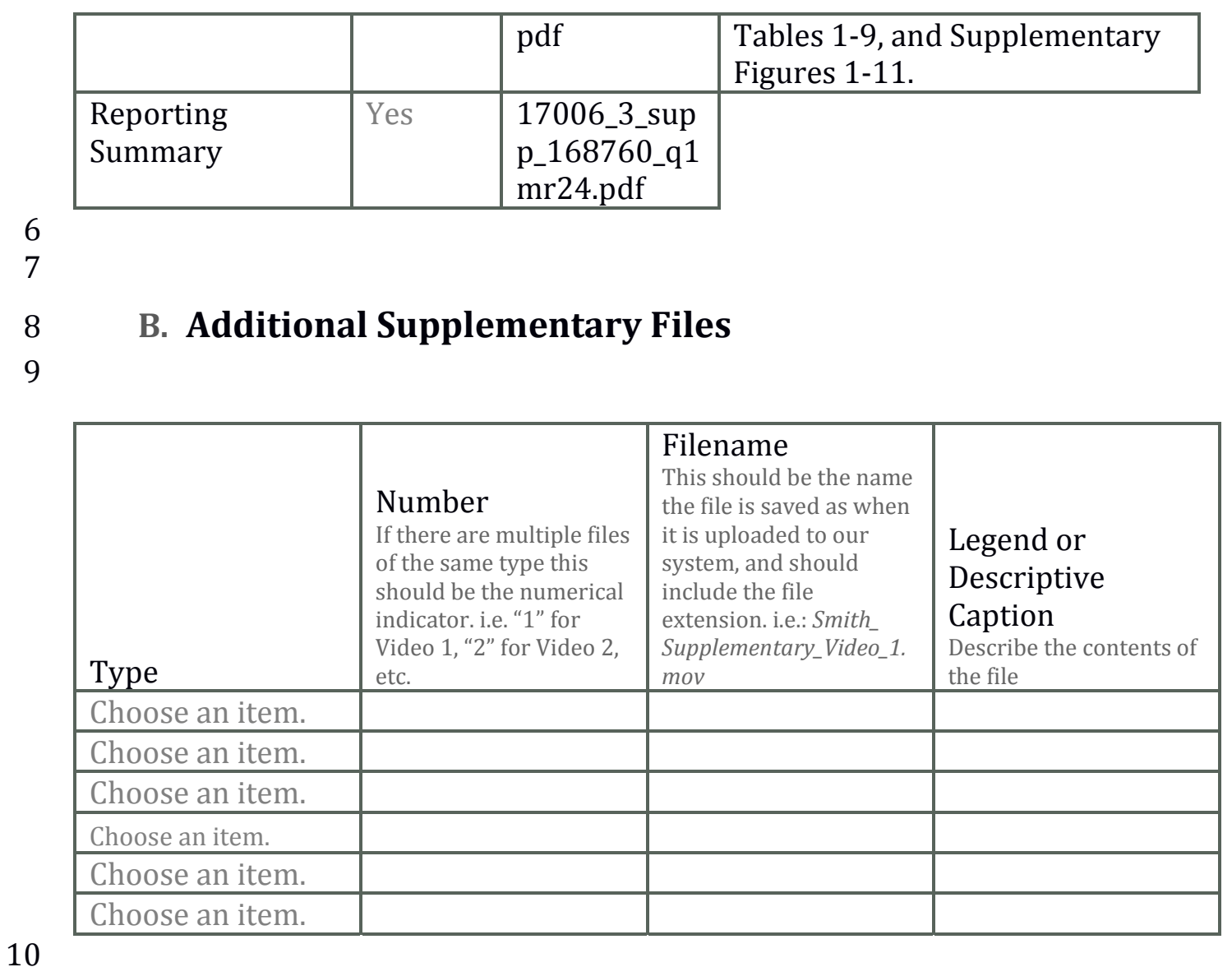

\section{3. Source Data}

12

\begin{tabular}{|c|c|c|}
\hline $\begin{array}{l}\text { Parent Figure } \\
\text { or Table }\end{array}$ & $\begin{array}{l}\text { Filename } \\
\text { This should be the name the } \\
\text { file is saved as when it is } \\
\text { uploaded to our system, and } \\
\text { should include the file } \\
\text { extension. i.e.: } \\
\text { Smith_SourceData_Fig1.xls, } \\
\text { or Smith__ } \\
\text { Unmodified_Gels_Fig1.pdf }\end{array}$ & $\begin{array}{l}\text { Data description } \\
\text { e.g.: Unprocessed Western Blots and/or } \\
\text { gels, Statistical Source Data, etc. }\end{array}$ \\
\hline \multicolumn{3}{|l|}{$\begin{array}{l}\text { Source Data } \\
\text { Fig. } 1\end{array}$} \\
\hline \multicolumn{3}{|l|}{$\begin{array}{l}\text { Source Data } \\
\text { Fig. } 2\end{array}$} \\
\hline \multicolumn{3}{|l|}{$\begin{array}{l}\text { Source Data } \\
\text { Fig. } 3\end{array}$} \\
\hline \multicolumn{3}{|l|}{$\begin{array}{l}\text { Source Data } \\
\text { Fig. } 4\end{array}$} \\
\hline \multicolumn{3}{|l|}{$\begin{array}{l}\text { Source Data } \\
\text { Fig. } 5\end{array}$} \\
\hline $\begin{array}{l}\text { Source Data } \\
\text { Fig. } 6\end{array}$ & & \\
\hline
\end{tabular}




\begin{tabular}{|l|l|l|}
\hline Source Data & & \\
Fig. 7 & & \\
\hline Source Data & & \\
Fig. 8 & & \\
\hline Source Data & & \\
Extended & & \\
Data Fig. 1 & & \\
\hline Source Data & & \\
Extended & & \\
Data Fig. 2 & & \\
\hline Source Data & & \\
Extended & & \\
Data Fig. 3 & & \\
\hline Source Data & & \\
Extended & & \\
Data Fig. 4 & & \\
\hline Source Data & & \\
Extended & & \\
Data Fig. 5 & & \\
\hline Source Data & & \\
Extended & & \\
Data Fig. 6 & & \\
\hline Source Data & & \\
Extended & & \\
Data Fig. 7 & & \\
\hline Source Data & & \\
Extended & & \\
Data Fig. 8 & & \\
\hline Source Data & & \\
Extended & & \\
Data Fig. 9 & & \\
\hline Source Data & & \\
Extended & & \\
Data Fig. 10 & & \\
\hline
\end{tabular}


 \\ Natural halogens buffer tropospheric ozone in a changing}

climate

Fernando Iglesias-Suarez ${ }^{1 \dagger}$, Alba Badia ${ }^{1}$, Rafael P. Fernandez ${ }^{1,2}$, Carlos A.

Cuevas $^{1}$, Douglas E. Kinnison ${ }^{3}$, Simone Tilmes ${ }^{3}$, Jean-François Lamarque ${ }^{3}$,

Mathew C. Long ${ }^{4}$, Ryan Hossaini ${ }^{5}$ and Alfonso Saiz-Lopez ${ }^{1, *}$

${ }^{1}$ Department of Atmospheric Chemistry and Climate, Institute of Physical Chemistry Rocasolano, CSIC, Serrano 119, 28006 Madrid, Spain.

${ }^{2}$ National Research Council (CONICET), FCEN-UNCuyo, UTN-FRM, Mendoza 5501, Argentina.

${ }^{3}$ Atmospheric Chemistry Observations and Modelling, NCAR, Boulder, CO 80301, USA.

${ }^{4}$ Climate and Global Dynamics Laboratory, NCAR, Boulder, CO 80301, USA.

${ }^{5}$ Lancaster Environment Centre, Lancaster University, Lancaster, UK.

†Present address: Deutsches Zentrum für Luft- und Raumfahrt (DLR), Institut für Physik der Atmosphäre, Oberpfaffenhofen, Germany.

*Correspondence to: Alfonso Saiz-Lopez (a.saiz@csic.es)

\section{Abstract}

Reactive atmospheric halogens destroy tropospheric ozone $\left(\mathrm{O}_{3}\right)$, an air pollutant and greenhouse gas. The primary source of natural halogens is emissions from marine phytoplankton and algae, as well as abiotic sources from ocean and tropospheric chemistry, but how their fluxes will change under climate warming -and the resulting impacts on $\mathrm{O}_{3}-$ are not well known. Here we use an Earth system model to estimate that natural halogens deplete approximately $13 \%$ of tropospheric $\mathrm{O}_{3}$ in the presentday climate. Despite increased levels of natural halogens through the twenty-first century, this fraction remains stable due to compensation from hemispheric, regional, and vertical heterogeneity in tropospheric $\mathrm{O}_{3}$ loss. Notably, this halogen-driven $\mathrm{O}_{3}$ buffering is projected to be greatest over polluted and populated regions, mainly due

Tropospheric $\mathrm{O}_{3}$ is a trace gas that plays a key role in atmospheric chemistry, both as

54 a greenhouse gas and as a component of photochemical smog, affecting air quality 55 and public health. ${ }^{1,2}$ Its abundance is controlled by a balance between in-situ 
56 photochemistry, stratospheric influx and surface dry deposition. ${ }^{3}$ Photochemical 57 destruction of $\mathrm{O}_{3}$ occurs throughout the troposphere, primarily via its photolysis and subsequent reaction with water vapor and direct loss by reaction with hydrogen radicals. ${ }^{4}$ Tropospheric $\mathrm{O}_{3}$ is also destroyed by reactions with reactive halogens $(\mathrm{Cl}$,

$60 \mathrm{Br}$, I) through catalytic cycles, and its budget can only be understood when 61 tropospheric halogen chemistry is included..$^{5-8}$ Indeed, halogens are now increasingly 62 recognized by observational and modelling work as an important component of 63 tropospheric chemistry. ${ }^{9,10}$ At present, they are estimated to reduce the global 64 tropospheric $\mathrm{O}_{3}$ burden by about $10-20 \%$, having a large impact on surface $\mathrm{O}_{3}$. ${ }^{7,8,11,12}$ 65 Biogenic very short-lived (VSL) halocarbons -including $\mathrm{CHBr}_{3}, \mathrm{CH}_{2} \mathrm{Br}_{2}$, $66 \mathrm{CH}_{3} \mathrm{I}$ and $\mathrm{CH}_{2} \mathrm{ICl}$ - are naturally emitted from the ocean via the metabolism of marine 67 organisms such as phytoplankton, micro- and macroalgae. These halogen compounds 68 have lifetimes of fewer than $\sim 6$ months and are important sources of reactive chlorine, 69 bromine and iodine to the troposphere. ${ }^{13}$ Furthermore, experimental research 70 demonstrates that the ocean is an abiotic source of inorganic iodine. This is a result of $71 \mathrm{O}_{3}$ deposition into the ocean and subsequent oxidation of seawater iodide to 72 hypoiodous acid (HOI) and molecular iodine $\left(\mathrm{I}_{2}\right)$, which are released to the 73 atmosphere. ${ }^{14,15}$ In the troposphere, reactive bromine and chlorine effectively results 74 from the photo-oxidation of VSL halocarbons, ${ }^{11,16,17}$ whereas oceanic emissions of 75 inorganic iodine can account for up to $75 \%$ of its atmospheric budget. ${ }^{18}$

76 Changes in climate and socio-economic development have already altered 77 natural fluxes of VSL halocarbons ( 7\% increase between 1979 and 2013$)^{19}$ and 78 inorganic iodine (tripled during 1950-2010) ${ }^{20,21}$ and will likely continue doing so 79 during the $21^{\text {st }}$ century. Previous studies have shown that climate change -primarily 80 warming sea surface temperatures (SSTs) - can accelerate air-sea exchange up to $\sim 30$ $81 \%$ for some halogenated VSL species ${ }^{19,22}$ by the end of the century. However, how 82 changes in naturally-emitted halogens will affect $\mathrm{O}_{3}$ and tropospheric chemistry and 83 climate remains unknown.

84 In this study, we use the Community Earth System Model (CESM) ${ }^{23}$ to project 85 emissions of organic and inorganic halogens in a consistent framework coupled to 86 climate and atmospheric composition (see Methods), to quantify their influence on 87 tropospheric $\mathrm{O}_{3}$ during 2000-2100. Low- and high-end Representative Concentration 88 Pathway (RCP) emission scenarios -including RCP2.6, RCP6.0 and RCP8.5- are 
explored, providing a range and upper limit estimate of potential impacts. We find

90 that global tropospheric $\mathrm{O}_{3}$ loss due to the inclusion of reactive halogens is nearly constant regardless of the emission scenario, linked to the buffering capacity of the natural system against external forcing. Our results reveal that over the century, enhanced 'near'-surface $\mathrm{O}_{3}$ loss by halogens offsets the negative effects of climate and air quality from $\mathrm{O}_{3}$ pollution over continental regions.

\section{Natural halogen emissions during the $21^{\text {st }}$ century}

97 Globally, present-day (defined as the 1990-2009 climatological mean; nominally year 98 2000) natural sources of organic VSL represented in the model -including nine 99 halocarbons containing chlorine, bromine and iodine- ${ }^{13,24}$ are approximately 1.22

$100 \mathrm{Tg}(\mathrm{Cl}, \mathrm{Br}, \mathrm{I}) \mathrm{yr}^{-1}$. Bromocarbon emissions are slightly larger $\left(0.63 \mathrm{Tg}(\mathrm{Br}) \mathrm{yr}^{-1}\right)$ than 101 iodocarbons $\left(0.52 \mathrm{Tg}(\mathrm{I}) \mathrm{yr}^{-1}\right)$, whereas chlorocarbons represent only a small 102 contribution $\left(0.07 \mathrm{Tg}(\mathrm{Cl}) \mathrm{yr}^{-1}\right)$. Geographically, these emissions are concentrated in 103 the tropics $\left(\sim 55 \%\right.$ between $\left.20^{\circ} \mathrm{N}-20^{\circ} \mathrm{S}\right)$ and at midlatitudes $(\sim 40 \%$ including both 104 hemispheres), with a marginal contribution from polar regions. In addition to its 105 organic sources, iodine is emitted from the ocean via an abiotic route, following $\mathrm{O}_{3}$ 106 deposition to the surface ocean. ${ }^{14,15}$ Hence, inorganic iodine emissions largely depend 107 on the atmospheric $\mathrm{O}_{3}$ burden and its deposition to the ocean, but also on SSTs and 108 wind speed. ${ }^{14}$ Here, modelled present-day global emissions of inorganic iodine are $1092.67 \mathrm{Tg}(\mathrm{I}) \mathrm{yr}^{-1}$, mainly confined within subtropical regions $\left(\sim 85 \%\right.$ between $35^{\circ} \mathrm{N}-$ $\left.11035^{\circ} \mathrm{S}\right)$. Climate change can have a significant impact on organic and inorganic natural 111 halogen fluxes via changes in physical factors (e.g. SSTs), ${ }^{25,26}$ biogeochemical cycles 112 (e.g. ocean organisms and nutrients availability), ${ }^{27-29}$ and socio-economic 113 developments (e.g. $\mathrm{O}_{3}$ precursors). ${ }^{20}$

114 Global and annual mean VSL halocarbon fluxes during 2000-2100 are shown 115 in Figure 1a. Physical climate-induced ("cliVSL" case; Supplementary Table 1) 116 changes in VSL halocarbon emissions increase by approximately $7.4 \%$ and $13.5 \%$ 117 for the RCP6.0 and RCP8.5 scenarios, respectively, by the end of the century (defined 118 as the climatological mean during 2080-2099; nominally year 2100) compared to 119 present-day. The rates of change of these fluxes are quasi-linear for both emission 120 scenarios and are primarily driven by changes occurring in midlatitudes (i.e., regions 121 with the largest SST changes relative to the year 2000 along with the tropics, 
122 Supplementary Fig. 1). A sensitivity case for the RCP2.6 scenario (year 2100;

123 Supplementary Table 2) projects $3.5 \%$ increases in VSL halocarbon emissions

124 (Supplementary Tables 3-7). Earth system models project a drop in global marine net 125 primary production associated with a warming climate over the $21^{\text {st }}$ century, ${ }^{27-29}$

126 which will affect the production of halogen compounds in marine waters

127 (acknowledging a limited processed-based understanding). ${ }^{30}$ Globally, our sensitivity

128 simulations, including physical and biogeochemical changes related to climate

129 ("cli+bioVSL"), show that declining marine primary production ( $4 \%$ by 2080$)$

130 results in approximately 2-3\% lower halocarbon emissions since mid-century, 131 compared to the "cliVSL" case. Changes in marine primary production are highly 132 heterogeneous due to a balance between direct (e.g., increase in phytoplankton 133 metabolic rates) and indirect (e.g., water stratification and nutrient limitations) 134 effects. ${ }^{27}$ The relatively small global drop in halocarbon emissions associated with 135 changes in marine net primary production is the consequence of mid-to-high-latitude 136 increases offset by larger decreases in tropical and subtropical regions.

137 In the above scenarios, future halocarbon emissions change in response to 138 physical forcing and marine primary production. Due to uncertainties in the future 139 evolution of these emissions, we additionally extrapolate trends from the recent past 140 (1979-2013) out to 2100 ("obsVSL"; Supplementary Table 3), resulting in the largest $141(18.1 \%)$ increase in VSL halocarbon emissions compared to present. While this 142 monotonic increase in emissions (Fig. 1) likely represents an upper limit, we note that 143 under each scenario considered, VSL halocarbon emissions are larger at the end of the $14421^{\text {st }}$ century compared to present.

$145 \quad$ Future inorganic iodine emissions are largely driven by socio-economic 146 development and associated evolution of atmospheric $\mathrm{O}_{3}$ and its deposition to the 147 ocean. Most $\mathrm{O}_{3}$ precursor emissions decrease during the century in the RCP scenarios, 148 particularly since mid-century. ${ }^{31}$ Methane emissions decrease and are relatively 149 unchanged for RCP2.6 and RCP6.0, respectively, while they double by 2100 150 compared to present for the RCP8.5 scenario. ${ }^{32}$ While $\mathrm{O}_{3}$ deposition to the ocean 151 increases $5.7 \pm 1.8 \%$ under RCP8.5 during 2000-2100 compared to present-day (260 $152 \pm 1 \mathrm{Tg}\left(\mathrm{O}_{3}\right) \mathrm{yr}^{-1}$; uncertainty range refers to one-sigma of the standard error unless 153 otherwise specified), it decreases $-16.8 \pm 3.3 \%$ and $-28.0 \%$ for RCP6.0 and 154 RCP2.6, respectively. In turn, global oceanic emissions of inorganic iodine increase 
155 by $\sim 20 \%$ following RCP8.5 over the same period, and they decrease around $10 \%$ 156 and $20 \%$ for RCP6.0 and RCP2.6, respectively (Fig. 1b).

157 Modelled changes in global and annual mean tropospheric concentrations of 158 reactive halogens over the century are shown in Figure 1c. Present-day globally 159 integrated tropospheric concentrations of reactive inorganic chlorine, bromine and 160 iodine are approximately $2.7 \mathrm{ppt}, 1.8 \mathrm{ppt}$ and $1.0 \mathrm{ppt}$ from natural sources, and 9.6 161 ppt, $1.9 \mathrm{ppt}$ and $1.0 \mathrm{ppt}$ including both anthropogenic and natural sources, 162 respectively. By 2100, reactive halogen concentrations increase by approximately 4 $16310 \%$, which depend on the precursor emission scenario and forcing, i.e. climate $(\sim 4$ $164 \%)$ and marine production (1-2\%). While bromine drives these changes under 165 RCP6.0, iodine shows no significant change as a result of the interplay between 166 iodocarbons (increasing) and inorganic iodine (decreasing) fluxes. In contrast, both 167 bromine and iodine contribute equally to the change in reactive halogen loading for

168 RCP8.5. Reactive halogen concentrations decrease for the RCP2.6 scenario ( $~ 5 \%)$.

169

170 Natural halogen impacts on $21^{\text {st }}$ century tropospheric ozone

171 The change in global tropospheric column-integrated $\mathrm{O}_{3}$ during 2000-2100 is shown 172 in Figure 2 (the tropospheric $\mathrm{O}_{3}$ budget is also given in Supplementary Table 8). The 173 upper and middle panels present absolute changes in tropospheric $\mathrm{O}_{3}$ column and its 174 loss associated with reactive halogens, respectively. Compared to present-day, 175 halogen-driven tropospheric $\mathrm{O}_{3}$ column loss increases towards mid-century, 176 coinciding with ever-rising VSL halocarbon emissions for RCP6.0 and RCP8.5. Two 177 different stories are drawn during the second half of the century. The impact of 178 reactive halogens on tropospheric $\mathrm{O}_{3}$ remains relatively unchanged by 2100 under 179 RCP8.5, whereas smaller depletion is projected under RCP6.0. This response is 180 closely linked to the total amount of tropospheric $\mathrm{O}_{3}$ and the key role of halogen 181 chemistry acting as a natural buffer (i.e., negative geochemical feedback; Fig. 1b). ${ }^{8}$ 182 Hence, greater tropospheric $\mathrm{O}_{3}$ results in an enhanced halogen-mediated loss and vice 183 versa. Notably, only a projection with constant natural halogen emissions ("fixVSL") 184 shows a disruption of the above natural buffering capacity linked to halogen 185 chemistry. One might think that increasing VSL halocarbon emissions in a changing 186 climate would result in greater tropospheric $\mathrm{O}_{3}$ loss. Counterintuitively, however, 187 global halogen-driven tropospheric $\mathrm{O}_{3}$ column loss is projected to remain nearly 
188 constant throughout the century $(\sim 12.8 \pm 0.8 \%)$ regardless the emissions scenario 189 (lower panel in Fig. 2), including the RCP2.6 (not shown).

190 Zonal mean tropospheric $\mathrm{O}_{3}$ loss associated with halogen chemistry for 191 present-day are illustrated in Figure 3a,b. On average, zonal mean loss of $\mathrm{O}_{3}$ mass is $192 \sim 0.3$ DU (3.9 DU globally integrated), to which bromine and iodine contribute 193 approximately $16 \%$ and $80 \%$, respectively. Although halogen-mediated tropospheric $194 \mathrm{O}_{3}$ loss mixing ratios peak in the extratropical upper troposphere associated with 195 stratospheric $\mathrm{O}_{3}$ depletion, the largest impacts of natural halogens on $\mathrm{O}_{3}$ mass are 196 simulated in the free troposphere (65\% of the total loss occurs between $300-850$ $197 \mathrm{hPa}$ ). Halogen-mediated $\mathrm{O}_{3}$ loss shows a clear hemispheric asymmetry -greater in the 198 SH at present- consistent with differences in ozone precursors and bromine-mediated 199 loss. VSL bromocarbons provide approximately $5 \pm 2 \mathrm{ppt}$ of bromine to the 200 stratosphere (i.e., on top of the brominated long-lived species), ${ }^{11,16,17}$ resulting in 201 additional stratospheric $\mathrm{O}_{3}$ depletion. ${ }^{33}$ In the extratropical $\mathrm{SH}$, the stratospheric 202 influx of $\mathrm{O}_{3}$ is affected by a strong chemistry-climate feedback whereby a colder 203 lower stratosphere due to halogenated VSL-driven $\mathrm{O}_{3}$ loss further enhances 204 stratospheric $\mathrm{O}_{3}$ depletion via heterogeneous activation. This controls up to $70 \%$ of 205 the tropospheric signal (Supplementary Fig. 5). ${ }^{7}$ Smallest tropospheric $\mathrm{O}_{3}$ decreases 206 are constrained to the tropical lower and upper troposphere (regions largely controlled 207 by reactions with water vapor and odd hydrogen radicals respectively). The 208 pronounced gradient in relative $\mathrm{O}_{3}$ loss (Fig. 3b), increasing from upper to lower 209 troposphere and from north to south, responds to the $\mathrm{O}_{3}$ burden distribution in the 210 troposphere.

211 Zonal mean tropospheric $\mathrm{O}_{3}$ loss trends $\left(\% \mathrm{dec}^{-1}\right)$ driven by natural halogens 212 during 2000-2100 for RCP6.0 and RCP8.5 are shown in Figures 3c,d. The resulting 213 pattern is heterogeneous, with marked hemispheric and vertical gradients, though 214 consistent for both emission scenarios (with differences in strength). Interestingly, the 215 relative $\mathrm{O}_{3}$ loss driven by reactive halogens weakens in the mid- and upper 216 troposphere during the century (10-20\% at $250 \mathrm{hPa}$; Fig. $4 \mathrm{a})$, which is explained by 217 an enhanced stratospheric influx due to greater stratospheric $\mathrm{O}_{3}$ levels and rapid 218 general circulation. ${ }^{34}$ This feature is amplified at high latitudes in the SH during the 219 first and second half of the century (Supplementary Fig. 8), linked to a strong 220 chemistry-climate feedback and the expected ozone hole recovery. Furthermore, in 
221 the tropical free troposphere between 300 and $850 \mathrm{hPa}$, future $\mathrm{O}_{3}$ loss by halogens 222 decreases towards the end of the century, suggesting that $\mathrm{O}_{3}$ fate in this region will be 223 primarily controlled by other drivers, including photolysis and reactions with water 224 vapor and hydroxyl radicals (Fig. 3c-d and Fig. 4b). By contrast, in the lower 225 troposphere, halogen-driven $\mathrm{O}_{3}$ loss is projected to be larger towards 2100, 226 accentuated during the second half of the century owing to decreases in $\mathrm{O}_{3}$ precursor 227 emissions (Supplementary Fig. 8b). We find a pronounced hemispheric asymmetry 228 with a greater $\mathrm{O}_{3}$ loss trend in the more "polluted" $\mathrm{NH}$ than in the "cleaner" $\mathrm{SH}$. 229 Compared to present-day, future halogen-mediated $\mathrm{O}_{3}$ loss is projected to increase by 230 up to $10-35 \%$ depending on the region and the emission scenario (Fig. 4), being 231 largest within the boundary layer.

232 'Near'-surface (define here as the average over the first kilometer) $\mathrm{O}_{3}$ loss 233 change between present-day and the end of the $21^{\text {st }}$ century is shown in Figure 5 . 234 Globally, natural halogen-induced near-surface $\mathrm{O}_{3}$ loss change between 2000 and 2352100 is greater for the RCP6.0 scenario ( $-15.0 \pm 1.1 \%)$ compared to RCP8.5 $(-3.1 \pm$ $2360.7 \%$; Supplementary Table 9). A consistent feature for both emission scenarios is 237 that, while relatively small or even weaker losses are predicted in the tropics (e.g., the 238 Western Pacific region), enhanced $\mathrm{O}_{3}$ loss is confined mainly to the extra-tropics, 239 peaking at midlatitudes $\left(30^{\circ}-60^{\circ}\right)$ (Fig. 5b,d).

240 Naturally-emitted halocarbons are relatively long-lived within the 241 troposphere. ${ }^{16,17}$ Thus, they can be transported from the oceans over the continents, 242 resulting in significant concentrations of reactive inorganic species. We find that the 243 largest $\mathrm{O}_{3}$ loss is projected to occur towards the end of the century over polluted 244 continental regions rather than in remote marine environments, with a marked 245 hemispheric asymmetry. Particularly, large halogen-driven $\mathrm{O}_{3}$ losses are anticipated 246 over the eastern United States, Europe, and eastern Asia of $-71.5 \pm 12.9 \%,-30.9 \pm$ $2474.2 \%$, and $-6.9 \pm 10.1 \%$ for RCP6.0, and $-48.2 \pm 12.6 \%,-18.3 \pm 3.2 \%$ and -23.2 $248 \pm 10.9 \%$ for RCP8.5 (Fig. 6). Future changes in near-surface $\mathrm{O}_{3}$ loss due to reactive 249 halogens are robust in this set of simulations for the emission scenarios considered 250 here (Supplementary Table 9). No significant differences are generally found between 251 RCP2.6 and RCP6.0, though larger differences are found compared to RCP8.5, 252 associated with a warmer and moister climate coupled to greater methane 253 concentrations. 
The impact of natural halogens on surface $\mathrm{O}_{3}$ is largely driven by iodine

255 catalytic cycles, especially over polluted areas that experience the largest change in 256 future $\mathrm{O}_{3}$ precursor emissions (Supplementary Fig. 11). The relative shift in surface $257 \mathrm{O}_{3}$ loss chemistry over polluted regions, towards a more iodine-mediated chemical 258 processing, is compensated by a relative decrease in other key families (i.e., 259 photolysis and reaction with water vapor and direct loss via hydrogen radicals).

260

\section{Discussion and concluding remarks}

262 Very short-lived halocarbons are naturally emitted from the ocean and strongly linked 263 to climate (primarily SSTs); ${ }^{13}$ whereas inorganic iodine emissions depend on $\mathrm{O}_{3}$ 264 deposition to the ocean. ${ }^{14,15}$ Therefore, future changes in fluxes and distributions of 265 natural halogens will be determined by a combination of climate sensitivity, future 266 anthropogenic emissions, and atmospheric chemistry.

267 Marine biota will be influenced by a number of factors as climate changes 268 (e.g., acidification, nutrients availability, water temperatures and stratification), which 269 will affect seawater concentrations of halocarbons and, therefore, their sea-to-air 270 fluxes. Here, changes in physical factors coupled with ocean biogeochemical cycles result in a relatively small drop in global VSL halocarbon fluxes ( $2-3 \%$; see Fig. 1$)$, although it shows a marked geographical re-distribution. Natural halocarbon emissions remained largely unchanged in the tropics ( $\pm 1 \%$ ) compared to present-day, compensated by larger increases at higher latitudes. Although global VSL halocarbon emissions are smaller when changes in marine net primary production are included ("cli+bioVSL") compared to when they are neglected ("cliVSL"), their impacts on tropospheric $\mathrm{O}_{3}$ loss generally are not significantly different at the $95 \%$ confidence interval in this analysis.

Surface $\mathrm{O}_{3}$ is highly sensitive to meteorological conditions and climate change. ${ }^{35}$ Strong observational and modelling evidence suggests that climate-related impacts over the next century will have negative effects for $\mathrm{O}_{3}$ pollution ('climate penalty'), ${ }^{36}$ though this is strongly dependent on future socio-economic development. By the end of the $21^{\text {st }}$ century, projections of near-surface $\mathrm{O}_{3}$ without halogens show relatively large decreases of $\sim 10-35 \%$ for the lower and middle end of the emission scenarios considered here (RCP2.6 and RCP6.0), and a range of -8 to $+2 \%$ for RCP8.5 over populated regions -eastern United States, Europe and eastern Asia- 
compared to the present ( $40-55 \mathrm{ppb})$, consistent with multi-model projections. ${ }^{36,37} \mathrm{~A}$

288 robust feature in our simulations is that near-surface $\mathrm{O}_{3}$ loss due to natural halogens 289 (mainly iodine) will be enhanced up to $\sim 70 \%$ over the eastern United States by 2100 290 compared to present-day (Figs. 5-6). For example, over the eastern United States, 291 halogen-driven near-surface $\mathrm{O}_{3}$ loss is predicted to deplete approximately an extra ppb 292 for the emission scenarios considered here (Supplementary Table 9), despite having 293 lower $\mathrm{O}_{3}$ levels by 2100 (8-25\%). Notably, the RCPs adopt stringent air quality 294 policies that reduce anthropogenic emissions of nitrogen oxides, carbon monoxide and 295 volatile organic compounds -though not methane- under RCP8.5. ${ }^{31,32}$ Should future 296 policies on anthropogenic emissions be more relaxed, such as the former Special 297 Report on Emission Scenarios ${ }^{38}$ (SRES) or the newly-adopted Shared Socioeconomic 298 Pathways $^{39}$ (SSP), the implications of halogen chemistry for surface $\mathrm{O}_{3}$ in a changing 299 climate (opposing the climate penalty effect) would be even more relevant for air 300 quality and human health.

301 In summary, we find that globally-integrated, halogen-driven tropospheric $\mathrm{O}_{3}$ 302 column loss is constant $(\sim 13 \%)$ throughout the $21^{\text {st }}$ century despite varying natural 303 halogen emissions. This is the result of a tradeoff between different regions.

304 Tropospheric $\mathrm{O}_{3}$ loss by halogens shows a marked hemispheric asymmetry for both 305 present-day and end-of-century. This work also reveals that the largest halogen306 mediated $\mathrm{O}_{3}$ losses (up to $70 \%$ ) are projected near the surface over polluted regions 307 of the NH (eastern United States, Europe and eastern Asia), with beneficial 308 implications for air quality and mitigating $\mathrm{O}_{3}$ pollution. We conclude that halogen 309 chemistry is a key component of the troposphere, controlling a large fraction of $\mathrm{O}_{3}$ at 310 present and determining its abundance and distribution under twenty-first-century 311 climate change.

\section{References}

314 1. Myhre D. Shindell, F.-M. Bréon, W. Collins, J. Fuglestvedt, J. Huang, D. 315 Koch, J.-F. Lamarque, D. Lee, B. Mendoza, T. Nakajima, A. Robock, G. Stephens, T. Takemura and H. Zhang, G. Anthropogenic and Natural Radiative Forcing. in Climate Change 2013: The Physical Science Basis. Contribution of Working Group I to the Fifth Assessment Report of the Intergovernmental Panel on Climate Change (ed. Stocker D. Qin, G.-K. Plattner, M. Tignor, S.K. Allen, J. Boschung, A. Nauels, Y. Xia, V. Bex and P.M. Midgley, T. F.) 659740 (Cambridge University Press, 2013). doi:10.1017/CBO9781107415324.018

2. UNEP: Environmental effects of ozone depletion and its interaction with 
3. Wild, O. Modelling the global tropospheric ozone budget: exploring the climate change: 2014 assessment, United Nations Environ- ment Programme (UNEP), Nairobi, 2015.

variability in current models. Atmos. Chem. Phys. 7, 2643-2660 (2007).

4. Monks, P. S. et al. Tropospheric ozone and its precursors from the urban to the global scale from air quality to short-lived climate forcer. Atmos. Chem. Phys. 15, 8889-8973 (2015).

5. Read, K. A. et al. Extensive halogen-mediated ozone destruction over the tropical Atlantic Ocean. Nature 453, 1232-1235 (2008).

6. Saiz-Lopez, A. et al. Estimating the climate significance of halogen-driven ozone loss in the tropical marine troposphere. Atmos. Chem. Phys. 12, 3939 3949 (2012).

7. Saiz-Lopez, A. et al. Iodine chemistry in the troposphere and its effect on ozone. Atmos. Chem. Phys. 14, 13119-13143 (2014).

8. Prados-Roman, C. et al. A negative feedback between anthropogenic ozone pollution and enhanced ocean emissions of iodine. Atmos. Chem. Phys. 15, 2215-2224 (2015).

9. Saiz-Lopez, A. \& von Glasow, R. Reactive halogen chemistry in the troposphere. Chem. Soc. Rev. 41, 6448 (2012).

10. Simpson, W. R., Brown, S. S., Saiz-Lopez, A., Thornton, J. A. \& Von Glasow, R. Tropospheric Halogen Chemistry: Sources, Cycling, and Impacts. Chem. Rev. 115, 4035-4062 (2015).

11. Fernandez, R. P., Salawitch, R. J., Kinnison, D. E., Lamarque, J. F. \& SaizLopez, A. Bromine partitioning in the tropical tropopause layer: Implications for stratospheric injection. Atmos. Chem. Phys. 14, 13391-13410 (2014).

12. Sherwen, T. et al. Global impacts of tropospheric halogens $(\mathrm{Cl}, \mathrm{Br}, \mathrm{I})$ on oxidants and composition in GEOS-Chem. Atmos. Chem. Phys. 16, 1223912271 (2016).

13. Ordóñez, C. et al. Bromine and iodine chemistry in a global chemistry-climate model: Description and evaluation of very short-lived oceanic sources. Atmos. Chem. Phys. 12, 1423-1447 (2012).

14. Carpenter, L. J. et al. Atmospheric iodine levels influenced by sea surface emissions of inorganic iodine. Nat. Geosci. 6, 108-111 (2013).

15. MacDonald, S. M. et al. A laboratory characterisation of inorganic iodine emissions from the sea surface: dependence on oceanic variables and parameterisation for global modelling. Atmos. Chem. Phys. 14, 5841-5852 (2014).

16. World Meteorological Organization (WMO), Scientific Assessment of Ozone Depletion: 2014, World Meteorological Organization, Global Ozone Research and Monitoring Project-Report No. 55, 416 pp., Geneva, Switzerland, 2014.

17. WMO (World Meteorological Organization), Scientific Assessment of Ozone Depletion: 2018, Global Ozone Research and Monitoring Project-Report No. 58, 588 pp., Geneva, Switzerland, 2018.

18. Prados-Roman, C. et al. Iodine oxide in the global marine boundary layer. Atmos. Chem. Phys. 15, 583-593 (2015).

19. Ziska, F., Quack, B., Tegtmeier, S., Stemmler, I. \& Krüger, K. Future emissions of marine halogenated very-short lived substances under climate change. J. Atmos. Chem. 74, 245-260 (2017).

20. Cuevas, C. A. et al. Rapid increase in atmospheric iodine levels in the North Atlantic since the mid-20th century. Nat. Commun. 9, 1452 (2018). 
21. Legrand, M. et al. Alpine ice evidence of a three-fold increase in atmospheric iodine deposition since 1950 in Europe due to increasing oceanic emissions. Proc. Natl. Acad. Sci. U. S. A. 115, 12136-12141 (2018).

22. Falk, S. et al. Brominated VSLS and their influence on ozone under a changing climate. Atmos. Chem. Phys. 17, 11313-11329 (2017).

23. Tilmes, S. et al. Representation of the Community Earth System Model (CESM1) CAM4-chem within the Chemistry-Climate Model Initiative (CCMI). Geosci. Model Dev. 9, 1853-1890 (2016).

24. Bell, N. et al. Methyl iodide: Atmospheric budget and use as a tracer of marine convection in global models. J. Geophys. Res. Atmos. 107, ACH 8-1-ACH 8-12 (2002).

25. Ziska, F. et al. Global sea-to-air flux climatology for bromoform , dibromomethane and methyl iodide. Atmos. Chem. Phys. 13, 8915-8934 (2013).

26. Lennartz, S. T. et al. Modelling marine emissions and atmospheric distributions of halocarbons and dimethyl sulfide: the influence of prescribed water concentration vs. prescribed emissions. Atmos. Chem. Phys. 15, 11753-11772 (2015).

27. Krumhardt, K. M., Lovenduski, N. S., Long, M. C. \& Lindsay, K. Avoidable impacts of ocean warming on marine primary production: Insights from the CESM ensembles. Global Biogeochem. Cycles 31, 114-133 (2017).

28. Laufkötter, C. et al. Drivers and uncertainties of future global marine primary production in marine ecosystem models. Biogeosciences 12, 6955-6984 (2015).

29. Laufkötter, C. et al. Projected decreases in future marine export production: the role of the carbon flux through the upper ocean ecosystem. Biogeosciences 13, 4023-4047 (2016).

30. Stemmler, I., Hense, I. \& Quack, B. Marine sources of bromoform in the global open ocean - global patterns and emissions. Biogeosciences 12, 1967-1981 (2015).

31. van Vuuren et al. The representative concentration pathways: an overview. Clim. Change 109, 5-31 (2011).

32. Meinshausen, M. et al. The RCP greenhouse gas concentrations and their extensions from 1765 to 2300. Clim. Change 109, 213-241 (2011).

33. Fernandez, R. P., Kinnison, D. E., Lamarque, J., Tilmes, S. \& Saiz-lopez, A. Impact of biogenic very short-lived bromine on the Antarctic ozone hole during the 21 st century. Atmos. Chem. Phys. 17, 1673-1688 (2017).

34. Iglesias-Suarez, F. et al. Key drivers of ozone change and its radiative forcing over the 21st century. Atmos. Chem. Phys 18, 6121-6139 (2018).

35. Jacob, D. J. \& Winner, D. A. Effect of climate change on air quality. Atmos. Environ. 43, 51-63 (2009).

36. Fiore, A. M. et al. Global air quality and climate. Chem. Soc. Rev. 41, 66636683 (2012).

37. Young, P. J. et al. Pre-industrial to end 21 st century projections of tropospheric ozone from the Atmospheric Chemistry and Climate Model Intercomparison Project (ACCMIP). Atmos. Chem. Phys. 13, 2063-2090 (2013).

38. Nakicenovic, N. \& Swart, R. Special Report on Emissions Scenarios: A Special Report of Working Group III of the Intergovernmental Panel on Climate Change. (2000).

39. Rao, S. et al. Future air pollution in the Shared Socio-economic Pathways. 
Correspondence and requests for materials should be addressed to A.S.-L.

\section{Acknowledgments}

429 This study has received funding from the European Research Council Executive Agency under the

430 European Union's Horizon 2020 Research and Innovation programme (Project 'ERC-2016-COG

431726349 CLIMAHAL'). R.H. is supported by a NERC Independent Research Fellowship

432 (NE/N014375/1). CAM-Chem is a component of the Community Earth System Model (CESM), which is supported by the NSF and the Office of Science of the US Department of Energy. Computing resources were provided by NCAR's Climate Simulation Laboratory, which is sponsored by the NSF and other agencies. Computing resources, support and data storage are provided and maintained by the Computational and Information System Laboratory from the National Center of Atmospheric Research

\section{Author Contributions}

A.S.-L. devised the research. F.I.-S. and A.S.-L. initiated the study in collaboration with A.B., R.P.F., C.A.C., D.E.K., S.T., J-F.L., M.C.L. and R.H.; F.I.-S., with the help of A.B. and R.P.F., developed and performed the CAM-Chem simulations. All authors discussed the findings and commented on the manuscript. F.I.-S., and A.S.-L. wrote the manuscript with contributions from all authors.

Competing interests. The authors declare no competing interests.

\section{Additional information}

448 Supplementary information accompanies this manuscript at...

\section{Methods}

\section{CESM (CAM-Chem) model, experiment design and evaluation}

452 The community Earth System Model (CESM; version 1.1.1), with the Community Atmospheric Model 453 including interactive chemistry (CAM-Chem; version 4), ${ }^{40,41}$ was used to explore halogen-driven 454 tropospheric $\mathrm{O}_{3}$ loss in the $21^{\text {st }}$ century. The model extends from the surface to approximately $40 \mathrm{~km}$ 455 (3.5 hPa in the upper stratosphere) with 26 levels (18 levels below $100 \mathrm{hPa}$ ) and includes a horizontal 456 resolution of $1.9^{\circ} \times 2.5^{\circ}$ (latitude by longitude). The 'standard' chemical scheme represented in CAM457 Chem represents 169 species with comprehensive photochemistry (gas-phase and heterogeneous 458 reactions) coupled to the radiation scheme. ${ }^{23}$ In addition, the chemical mechanism here includes a stateof-the-art photochemistry scheme, heterogeneous recycling, wet and dry deposition for natural

460 halogens (containing chlorine, bromine and iodine) in the troposphere and the stratosphere..$^{6,711,42}$ 461 Natural halogen sources include both, biogenic and abiotic routes. Biogenic sources comprise 9 462 halocarbons $\left(\mathrm{CHBr}_{3}, \mathrm{CH}_{2} \mathrm{Br}_{2}, \mathrm{CH}_{2} \mathrm{BrCl}, \mathrm{CHBr} 2 \mathrm{Cl}, \mathrm{CHBrCl}_{2}, \mathrm{CH}_{3} \mathrm{I}, \mathrm{CH}_{2} \mathrm{I}_{2}, \mathrm{CH}_{2} \mathrm{IBr}\right.$, and $\left.\mathrm{CH}_{2} \mathrm{ICl}\right)$, 
which are the result of phytoplankton and (micro-) macroalgae metabolism and photochemistry at the ocean's surface. ${ }^{13}$ Abiotic iodine source gas $\left(\mathrm{HOI}\right.$ and $\mathrm{I}_{2}$ ) emissions are directly emitted from the ocean as a consequence of $\mathrm{O}_{3}$ deposition and reactions with seawater iodide. ${ }^{14,15}$ Present-day global inorganic iodine emissions in this set of simulations $\left(\sim 2.67 \mathrm{Tg}(\mathrm{I}) \mathrm{yr}^{-1}\right)$ are $\sim 40 \%$ higher than previously reported, ${ }^{8,20}$ reflecting differences in boundary conditions (e.g. $\mathrm{O}_{3}$ precursors and SSTs). Nevertheless,

468 tropospheric $\mathrm{O}_{3}$ deposition to the ocean modelled here $\left(260 \mathrm{Tg}\left(\mathrm{O}_{3}\right) \mathrm{yr}^{-1}\right)$ is within observational estimates (200-350 $\left.\mathrm{Tg}\left(\mathrm{O}_{3}\right) \mathrm{yr}^{-1}\right) \cdot{ }^{43}$ Concentrations of reactive halogens are defined for chlorine $\left(\mathrm{Cl}_{\mathrm{y}}=\right.$ $\left.\mathrm{Cl}+\mathrm{ClO}+2 \times \mathrm{Cl}_{2}+2 \times \mathrm{Cl}_{2} \mathrm{O}_{2}+\mathrm{OClO}+\mathrm{HOCl}+\mathrm{ClONO}_{2}+\mathrm{HCl}+\mathrm{BrCl}+\mathrm{ClNO}_{2}+\mathrm{ICl}\right)$, bromine $\left(\mathrm{Br}_{\mathrm{y}}=\right.$ $\left.\mathrm{Br}+\mathrm{BrO}+\mathrm{HOBr}+\mathrm{BrONO}_{2}+\mathrm{HBr}+\mathrm{BrCl}+2 \times \mathrm{Br}_{2}+\mathrm{BrNO}_{2}+\mathrm{IBr}\right)$, and iodine $\left(\mathrm{I}_{\mathrm{y}}=\mathrm{I}+2 \times \mathrm{I}_{2}+\mathrm{IO}+\right.$ $\left.\mathrm{OIO}+\mathrm{HI}+\mathrm{HOI}+\mathrm{INO}+\mathrm{INO}_{2}+\mathrm{IONO}_{2}+\mathrm{IBr}+\mathrm{ICl}+2 \times \mathrm{I}_{2} \mathrm{O}_{2}+2 \times \mathrm{I}_{2} \mathrm{O}_{3}+2 \times \mathrm{I}_{2} \mathrm{O}_{4}\right)$.

The model set-up was based on the Chemistry-Climate Model Initiative (CCMI) REFC2 experiment (transient simulation between 1960 and 2100). ${ }^{44}$ Future (2006-2100) projections followed the Representative Concentration Pathway emission scenarios RCP6.0 and RCP8.5. Monthly and seasonally varying boundary conditions were specified for $\mathrm{CO}_{2}, \mathrm{~N}_{2} \mathrm{O}, \mathrm{CH}_{4}$, as well as long-lived halogen-containing species $\left(\mathrm{CH}_{3} \mathrm{Cl}, \mathrm{CH}_{3} \mathrm{CCl}_{3}, \mathrm{CCl}_{4}, \mathrm{CFC}-11, \mathrm{CFC}-12\right.$, CFC-113, HCFC-22, CFC-114, CFC-115, HCFC-141b, HCFC-142b, $\mathrm{CH}_{3} \mathrm{Br}, \mathrm{H}-1301, \mathrm{H}-1211$, H-1202, and H-2402) following the A1 halogen scenario. ${ }^{45}$ Note that imposing long-lived gas concentrations as lower boundary conditions neglects the halogen-induced $\mathrm{CH}_{4}$ oxidation feedback. Detailed description of tropospheric bromine and iodine chemical processing included in the chemical scheme, for both day- and nighttime, has been documented in previous work, ${ }^{7,11,46,47}$ as well as an extensive evaluation of tropospheric mixing ratios of organic and inorganic halogenated species. ${ }^{13,18}$ Furthermore, modelled present-day $\mathrm{O}_{3}$-represented in CAM-Chem with an equivalent experimental set-up and the standard chemical scheme- has been recently evaluated against a number of observational data sets. ${ }^{23}$ Simulated tropospheric $\mathrm{O}_{3}$ column lies within \pm 10 DU compared to satellite measurements, showing best agreement in the tropics and midlatitudes during spring and summer, though largest deviations at midlatitudes during winter and fall. Regionally, simulated tropospheric $\mathrm{O}_{3}$ shows, both good agreement with available measurements $( \pm 25 \%)$, and skills reproducing observed features (e.g. $\mathrm{O}_{3}$ midlatitudes-to-tropics gradient and summertime maximum over the Mediterranean basin). The inclusion of natural halogen chemistry and emissions generally improves CAM-Chem's performance compared to observations (Supplementary Fig. 2).

The CAM-Chem including interactive chemistry was also used in specified dynamics (SD) mode, ${ }^{40}$ with equivalent emissions and boundary conditions to the reference simulations (transient runs) , present-day (year 2000) and the end of the $21^{\text {s }}$ century (year 2100). Three years of meteorological fields (every 3-hours) were derived from perpetual year 2000 and year 2100 (following three RCPs scenarios) simulations. The chemistry sensitivity simulations in SD mode were driven by identical meteorology (temperature, winds, and surface pressure), emissions and boundary conditions representative of both periods, present-day and year 2100, only natural halogens emissions and chemistry change ("SD-noVSL" and "SD-cliVSL" cases). All SD simulations were run for three years each, using initial conditions from the equivalent reference simulation (as a spun up), and the last year was used for the analysis. 
505 Sea-air gas flux $(\mathrm{F}){ }^{48}$ as implemented in CAM-Chem (following Johnson), ${ }^{49}$ is governed by its

506 exchange velocity $(\mathrm{k})$ and concentration gradient $(\Delta \mathrm{c})$ as follows:

$$
\mathrm{F}=\mathrm{k} \cdot \Delta \mathrm{c}=\mathrm{k} \cdot\left(\mathrm{c}_{\mathrm{w}}-\frac{\mathrm{c}_{\mathrm{a}}}{\mathrm{H}}\right)
$$

507 where $\mathrm{k}\left(=\left[1 / \mathrm{k}_{\mathrm{w}}+1 /\left(\mathrm{H} \mathrm{k}_{\mathrm{a}}\right)\right]^{-1}\right)$ is parameterized distinguishing between water- $\left(\mathrm{k}_{\mathrm{w}}\right)$ and air-phase $\left(\mathrm{k}_{\mathrm{a}}\right)$

508 exchange velocities (i.e. primarily determined by SSTs and surface wind speed), $\mathrm{c}_{\mathrm{w}}$ and $\mathrm{c}_{\mathrm{a}}$ are the gas seawater and air concentrations respectively, and $\mathrm{H}$ is the dimensionless Henry coefficient (i.e. temperature dependent gas-over-liquid expression of the Henry's law constant). Since k and H are dependent on climate-related physical factors, halocarbons fluxes will vary as climate changes.

Climate-induced changes in physical factors (i.e., SSTs and salinity) were used to drive changes in natural sources of organic halogens for the "cliVSL" case, while holding $\mathrm{c}_{\mathrm{w}}$ and $\mathrm{c}_{\mathrm{a}}$ constant.

514 Changes in VSL halocarbons were forced to depart from Ordoñez et al. ${ }^{13}$ emission inventory using the 515 ratio of the flux at a given time-step compared to that at present-day (i.e. monthly and seasonally 516 varying present-day climatology). Present-day (1990-2009) $\mathrm{c}_{\mathrm{w}}$ and $\mathrm{c}_{\mathrm{a}}$ of $\mathrm{CHBr}_{3}, \mathrm{CH}_{2} \mathrm{Br}_{2}$ and $\mathrm{CH}_{3} \mathrm{I}$ 517 were derived from a previous simulation (not used in this analysis) following Ordoñez et al. ${ }^{13}$ emission 518 inventory scaled to the inventory of Ziska et al. ${ }^{25}$ (scaling factor of 0.26, 1.19 and 1.06 respectively), as 519 follows:

$$
\Delta \mathrm{c}_{0}=\frac{\mathrm{F}_{0}}{\mathrm{k}_{0}} \cdot \text { scaling factor }
$$

where $\Delta \mathrm{c}_{0}, \mathrm{~F}_{0}$ and $\mathrm{k}_{0}$ are the concentration gradient, the sea-air gas exchange and the transfer velocity at present, respectively. Present-day sea-water halogen concentration $\left(\mathrm{c}_{\mathrm{w} 0}\right)$ was derived by:

$$
\mathrm{c}_{w 0}=\left(\Delta \mathrm{c}_{0}+\frac{\mathrm{c}_{a 0}}{\mathrm{H}_{0}}\right)
$$

522 where $c_{a 0}$ and $\mathrm{H}_{0}$ are the air halogen concentration and Henry coefficient (dimensionless) at present

523 from the model output. Therefore, $\Delta \mathrm{c}_{0}$ and $\mathrm{c}_{\mathrm{w} 0}$ are consistent with both, observationally derived 524 concentrations of Ziska et al. ${ }^{25}$ and VSL halogens distributions of Ordoñez et al. ${ }^{13}$ Due to the lack of a 525 global climatology for $\mathrm{c}_{\mathrm{w}}$ and $\mathrm{c}_{\mathrm{a}}$ of other halocarbons considered here, changes in their fluxes followed 526 that of $\mathrm{CHBr}_{3}\left(\mathrm{CHBr}_{2} \mathrm{Cl}\right.$ and $\left.\mathrm{CHBrCl}_{2}\right), \mathrm{CH}_{2} \mathrm{Br}_{2}\left(\mathrm{CH}_{2} \mathrm{BrCl}\right)$ and $\mathrm{CH}_{3} \mathrm{I}\left(\mathrm{CH}_{2} \mathrm{I}_{2}, \mathrm{CH}_{2} \mathrm{ICl}\right.$ and $\left.\mathrm{CH}_{2} \mathrm{IBr}\right)$. For 527 example, present-day fluxes for a given grid cell (or region) of $\mathrm{CH}_{2} \mathrm{Br}_{2}$ and $\mathrm{CH}_{2} \mathrm{BrCl}$ experienced 528 equivalent changes by 2100 . Note the VSL emission inventory used here does not include fluxes at the 529 sea-ice interface, and therefore its changes as SSTs warm during the century did not involve additional 530 emissions (sea-ice bromocarbon fluxes could contribute up to $10 \%$ to the tropospheric reactive 531 bromine abundances). ${ }^{50}$

532 Surface wind speed was held "constant" to drive future changes in VSL fluxes in this work 533 (i.e. using a present-day seasonally varying climatology). Instantaneous wind speed may cause errors 534 on gas-exchange fluxes, e.g. high-frequency wind variabilities can enhance fluxes more than a factor of

$5352 .^{51}$ Since we are projecting changes in halocarbon fluxes based on a monthly-mean emission inventory 536 for present-day, ${ }^{13}$ implementing instantaneous wind speed would have led to unreasonable fluxes (not 537 shown). Nevertheless, zonal mean changes in surface wind speed over the century are small compared 
538 to present-day (approximately $\pm 0.1 \mathrm{~ms}^{-1}$ or $\pm 2 \%$ ) and not believed to play an important role driving 539 natural halocarbon fluxes (consistent with previous work). ${ }^{22}$ Our simulated changes in VSL emissions

540 due to physical changes (i.e. SSTs and salinity in "cliVSL") are broadly consistent with previous

541 "offline" 19 and "semi-offline" 22 calculations -largest absolute and relative changes occur in the tropics

542 and poleward, respectively-, and differences are mainly associated with the underlying climate model

543 (i.e., changes in SSTs).

544 The Community Earth System Model large ensemble (CESM-LE; 34 ensemble members) 545 following the RCP8.5 emissions scenario, is used to explore varying spatial distributions and

546 magnitude of halocarbons emissions, resulting from anthropogenic-driven changes in marine primary 547 production ("cli+bioVSL"). This case represents a sensitivity study to the physical climate-induced 548 changes in VSL halocarbon emissions, providing a first order magnitude of $\mathrm{O}_{3}$ loss associated with 549 potential changes in biogeochemical cycles. We adopt a non-mechanistic approach by relating seawater 550 halocarbon concentrations to long-term changes in vertically integrated marine primary production ( $1: 1$ 551 correlation in relative terms). Although the approach adopted here advances the field with the specific 552 benefits of (a) being robust and (b) being relatively simple to implement in Earth system models, a 553 number of limitations and uncertainties should be noted. Future changes in marine primary production 554 simulated by CESM lies in the lower end of Earth system models. ${ }^{52}$ Changes in net primary production 555 used here -using the Community Atmospheric Model (CAM-Chem)- for the RCP8.5 emission 556 scenario are consistent (i.e., projected changes in SSTs between CESM-LE and CAM-Chem are 557 equivalent). However, these may have been overestimated for the RCP6.0 scenario (globally, the 558 difference in marine primary production between the RCP4.5 and RCP8.5 scenarios is approximately 2

$559 \%$ by the end of the century). ${ }^{27}$ Furthermore, current understanding in oceanic production of 560 halocarbons at the process-based level is limited. For example, bromoform in the open ocean can be in561 situ produced by phytoplankton (i.e., the amount produced varies among species) and can be, in part, 562 transported from coastal regions (i.e., mainly produced by macroalgae). ${ }^{30}$ Future research in the field 563 and its advances will benefit our understanding of natural halocarbon emissions in a changing climate.

564

\section{Oceanic inorganic iodine emissions}

566 Iodine is also emitted from the ocean via an abiotic route, due to the oxidation of aqueous iodide $\left(\mathrm{I}_{\text {aq }}^{-}\right)$ 567 following $\mathrm{O}_{3}$ deposition to seawater. The abiotic route of iodine emissions (HOI and $\mathrm{I}_{2}$ ) from the ocean 568 was first implemented in CAM-Chem by Prados-Roman et al. ${ }^{8}$ and dependent on surface $\mathrm{O}_{3}$ 569 concentration, wind speed, and SSTs as follows:

$$
\begin{aligned}
& \mathrm{F}_{\mathrm{HOI}}=\left[\text { surf. } \mathrm{O}_{3}\right] \times\left\{4.15 \times 10^{5} \times\left(\frac{\sqrt{\left[\mathrm{I}_{\mathrm{aq}}^{-}\right]}}{\mathrm{ws}}\right)-\left(\frac{20.6}{\mathrm{ws}}\right)-23,600 \times \sqrt{\left[\mathrm{I}_{\mathrm{aq}}^{-}\right]}\right\} \\
& \mathrm{F}_{\mathrm{I}_{2}}=\left[\text { surf. } \mathrm{O}_{3}\right] \times\left[\mathrm{I}_{\mathrm{aq}}^{-}\right]^{1.3}\left\{1.74 \times 10^{9}-\left(6.54 \times 10^{8} \times \ln \mathrm{ws}\right)\right\}
\end{aligned}
$$

570 where $\left[\right.$ surf. $\left.\mathrm{O}_{3}\right]$, ws and $\left[\mathrm{I}^{-}\right.$aq $]$represent surface $\mathrm{O}_{3}$ concentration $(\mathrm{ppb})$, wind speed $\left(\mathrm{ms}^{-1}\right)$ and aqueous

571 iodine concentration $\left(\mathrm{mol} \mathrm{dm}{ }^{-3}\right)$, respectively. ${ }^{14}\left[\mathrm{I}^{-}\right.$aq $]$is parameterized using SSTs as a proxy: ${ }^{53}$

$$
\left[\mathrm{I}_{\mathrm{aq}}^{-}\right]=1.46 \times 10^{6} \times \exp \left(\frac{-9134}{\mathrm{SST}}\right)
$$


Although observational studies found that SSTs are currently the best proxy for $\left[\mathrm{I}^{-}{ }_{\mathrm{aq}}\right],^{53,54}$ further research is needed to understand the processes involved in its distribution. Due to the parameterization used here results in lower $\left[\mathrm{I}_{\text {aq }}^{-}\right]$compared to Chance et al. ${ }^{54}$ and electronic affinity between $\mathrm{O}_{3}$ and iodide is neglected, inorganic iodine emissions in this work may be considered as a lower limit.

\section{Relative changes and trends in tropospheric ozone loss}

Relative changes and trends in $\mathrm{O}_{3}$ loss associated with natural halogens (normalized to $\mathrm{O}_{3}$ levels) are computed as follows:

$$
\Delta \mathrm{O}_{3} \operatorname{loss}_{\mathrm{i}, \mathrm{j}, \mathrm{k}, \mathrm{t}}=\frac{\left\{\left(\frac{\mathrm{O}_{3[\mathrm{VSL}]-} \mathrm{O}_{3[\text { noVSL }]}}{\mathrm{O}_{3[\text { noVSL }]}}\right)_{\mathrm{i}, \mathrm{j}, \mathrm{k}, \mathrm{t}}-\left(\frac{\mathrm{O}_{3[\mathrm{VSL}]-} \mathrm{O}_{3[\text { noVSL }]}}{\mathrm{O}_{3[\text { noVSL }]}}\right)_{\mathrm{i}, \mathrm{j}, \mathrm{k}, \mathrm{t}_{0}}\right\}}{\operatorname{abs}\left(\frac{\mathrm{O}_{3[\mathrm{VSL}]-} \mathrm{O}_{3[\text { noVSL }]}}{\mathrm{O}_{3[\text { noVSL }]}}\right)_{\mathrm{i}, \mathrm{j}, \mathrm{k}, \mathrm{t}_{0}}}
$$

where $t$ and $t_{0}$ refers to time (year) and present-day (1990-2009), respectively. Longitude, latitude and pressure level are represented by $\mathrm{i}, \mathrm{j}$ and $\mathrm{k}$ respectively, and [VSL] and [noVSL] are for the cases with and without natural halogens. Linear trends (Fig. 3) and time-series (Fig. 6) are calculated from $\Delta \mathrm{O}_{3} \operatorname{loss}_{\mathrm{i}, \mathrm{j}, \mathrm{k}, \mathrm{t}}$ and expressed in $\% \mathrm{dec}^{-1}$ and $\%$, respectively. Changes between present-day and the end of the $21^{\text {st }}$ century are also calculated from $\Delta \mathrm{O}_{3} \operatorname{loss}_{\mathrm{i}, \mathrm{j}, \mathrm{k}, \mathrm{t}}$, but $\mathrm{t}$ refers to the 2080-2099 period (Fig. 4 and 5). Future relative changes in halogen-driven tropospheric $\mathrm{O}_{3}$ loss normalized to $\mathrm{O}_{3}$ abundances, allow to explore halogen chemical processing impacts.

\section{Data availability}

The data used in this study are available from the corresponding author on reasonable request.

\section{Code availability}

The software code for the CESM model is available from http://www.cesm.ucar.edu/models/.

\section{References}

40. Lamarque, J. F. et al. CAM-chem: description and evaluation of interactive atmospheric chemistry in the Community Earth System Model. Geosci. Model Dev. 5, 369-411 (2012).

41. Neale, R. B. et al. The Mean Climate of the Community Atmosphere Model (CAM4) in Forced SST and Fully Coupled Experiments. J. Clim. 26, 51505168 (2013).

42. Saiz-Lopez, A. et al. Injection of iodine to the stratosphere. Geophys. Res. Lett. 42, 2015GL064796 (2015).

43. Ganzeveld, L., Helmig, D., Fairall, C. W., Hare, J. \& Pozzer, A. Atmosphereocean ozone exchange: A global modeling study of biogeochemical, atmospheric, and waterside turbulence dependencies. Global Biogeochem. Cycles 23, 0886-6236 (2009).

44. Morgenstern, O. et al. Review of the global models used within the ChemistryClimate Model Initiative (CCMI). Geosci. Model Dev. Discuss. 1-49 (2016). doi:10.5194/gmd-2016-199

45. WMO (World Meteorological Organization), Scientific Assessment of Ozone 
Depletion: 2010, Global Ozone Research and Monitoring Project-Report No. 52, 516 pp., Geneva, Switzerland, 2011.

46. Saiz-Lopez, A. \& Fernandez, R. P. On the formation of tropical rings of atomic halogens: Causes and implications. Geophys. Res. Lett. 43, 2928-2935 (2016).

47. Saiz-Lopez, A. et al. Nighttime atmospheric chemistry of iodine. Atmos. Chem. Phys. 16, 15593-15604 (2016).

48. Liss, P. S. \& Slater, P. G. Flux of Gases across the Air-Sea Interface. Nature 247, 181-184 (1974).

49. Johnson, M. T. A numerical scheme to calculate temperature and salinity dependent air-water transfer velocities for any gas. Ocean Sci. 6, 913-932 (2010).

50. Abrahamsson, K., Granfors, A., Ahnoff, M., Cuevas, C. A. \& Saiz-Lopez, A. Organic bromine compounds produced in sea ice in Antarctic winter. Nat. Commun. 9, 5291 (2018).

51. Bates, N. R. \& Merlivat, L. The influence of short-term wind variability on airsea CO 2 exchange. Geophys. Res. Lett. 28, 3281-3284 (2001).

52. Bopp, L. et al. Multiple stressors of ocean ecosystems in the 21st century: projections with CMIP5 models. Biogeosciences 10, 6225-6245 (2013).

53. MacDonald, S. M. et al. A laboratory characterisation of inorganic iodine emissions from the sea surface: dependence on oceanic variables and parameterisation for global modelling. Atmos. Chem. Phys. 14, 5841-5852 (2014).

54. Chance, R., Baker, A. R., Carpenter, L. \& Jickells, T. D. The distribution of iodide at the sea surface. Environ. Sci. Process. Impacts 16, 1841-1859 (2014).

55. CISL. Computational and Information Systems Laboratory. Cheyenne: HPE/SGI ICEXA System (NCAR Community Computing). (2017). doi:10.5065/D6RX99HX 
639 Figure 1 | Global and annual mean changes in natural halogens. a) Natural 640 sources of VSL halocarbon fluxes, b) inorganic iodine emissions, and c) tropospheric 641 natural reactive halogens concentrations (VSL cases minus "noVSL") from 2000 to 642 2100, following the RCP6.0 (blue) and RCP8.5 (red) emission scenarios. Changes are 643 shown for the "cliVSL" (solid), "obsVSL" (dashed), and "cli+bioVSL" (dotted) 644 simulations. VSL halocarbon fluxes for the "obsVSL" case are shown in black, 645 elsewhere RCP6.0 and RCP8.5 are differentiated. The shaded area represents the 646 range between the "cliVSL" (physical climate-induced only) and "cli+bioVSL" 647 (physical climate-induced and marine primary production) simulations. Natural 648 halogen fluxes both, organic and inorganic, are summarized in Supplementary Tables $6493-7$. Note (c) is with respect to present-day levels (only focusing on reactive inorganic 650 bromine and iodine, which represent $\sim 97 \%$ of the total halogen chemistry in the 651 troposphere). The tropopause is based on a chemical definition ("noVSL" $150 \mathrm{ppb}$ 652 ozone level) at present-day. The horizontal dashed black lines help compare changes 653 with present-day. Time-series, normalized through the origin, are smoothed applying 654 lowess filtering (0.2 fraction). 
655 Figure 2 | Global and annual mean tropospheric $\mathbf{O}_{3}$ column time-series from 6562000 to 2100. (upper panel), Absolute changes (DU); (middle panel) Absolute and 657 (lower panel) relative (\%) halogen-driven tropospheric $\mathrm{O}_{3}$ column loss (VSL cases 658 minus "noVSL"). Time-series are shown for the "cliVSL" (solid), "obsVSL" 659 (dashed), "cli+bioVSL" (dotted), and "fixVSL" (solid light) simulations. The shaded 660 area represents the range between the "cliVSL" (climate-induced only) and 661 "cli+bioVSL" (climate-induced and marine primary production) simulations. The 662 tropopause is based on a chemical definition ("noVSL" $150 \mathrm{ppb}$ ozone level) at 663 present-day. Time-series, normalized through the origin, are smoothed applying 664 lowess filtering (0.2 fraction).

665 
666 Figure 3 | Zonal mean tropospheric $\mathbf{O}_{3}$ loss due to reactive halogens. Present-day 667 halogen-mediated tropospheric $\mathrm{O}_{3}$ loss ("cliVSL" minus "noVSL") is shown in a) 668 absolute (DU) and b) relative (\%) values. Future trends in halogen-driven 669 tropospheric $\mathrm{O}_{3}$ loss $\left(\% \mathrm{dec}^{-1}\right)$ from 2000 to 2100 , relative to present-day and 670 normalized to $\mathrm{O}_{3}$ levels, are shown for the c) RCP6.0 and d) RCP8.5 emission 671 scenarios. Hatching indicates trends are not significant at the $95 \%$ confidence interval 672 (two-sigma of the standard error trend). The tropopause is based on a chemical 673 definition ("noVSL" $150 \mathrm{ppb}$ ozone level) at present-day. The full set of simulations 674 is included in the Supplementary Information, including the specified dynamics 675 simulations for the RCP2.6 scenario.

676 
677 Figure 4 | Vertically-resolved changes in partial column $\mathbf{O}_{3}$ loss due to reactive 678 halogens between present-day (1990-2009) and the end of the century (2080679 2099). Profiles are shown for: a) global; b) tropics; c) $\mathrm{NH}$; and d) $\mathrm{SH}$. Relative 680 changes are normalized to $\mathrm{O}_{3}$ levels. As Fig. 1, the results are shown for the RCP6.0 681 (blue) and RCP8.5 (red) emission scenarios, as well as the "cliVSL" (solid), 682 "obsVSL" (dashed), "cli+bioVSL" (dotted), and "fixVSL" (solid light) simulations. 683 The tropopause is based on a chemical definition ("noVSL" $150 \mathrm{ppb}$ ozone level) at 684 present-day.

685

686 
Figure 5 | Maps of halogen-driven 'near'-surface $O_{3}$ loss change between present-day (1990-2009) and the end of the century (2080-2099). Maps are shown for: a) the RCP6.0, and c) RCP8.5 emission scenarios ("cliVSL"). Changes are normalized to $\mathrm{O}_{3}$ levels. Near-surface $\mathrm{O}_{3}$ refers to the average of the four lowermost model layers (i.e. first kilometer). Hatchings are for not statistically significant changes at the $5 \%$ level using a two-tailed Student's $t$ test. Right panels show zonal mean $\mathrm{O}_{3}$ loss changes, as Fig. 1, for the b) RCP6.0 and d) RCP8.5 emission scenarios, as well as the "cliVSL" (solid), "obsVSL" (dashed), "cli+bioVSL" (dotted), and "fixVSL" (solid light) simulations. Zonal mean $\mathrm{O}_{3}$ loss changes are latitudinally weighted (i.e. using latitudinal cosines). The specified dynamics simulations are included in the Supplementary Information. 
Figure 6 | Halogen-driven 'near'-surface $O_{3}$ loss time-series from 2000 to 2100. Time-series are shown for: a) global, b) eastern United States $\left(95^{\circ} \mathrm{W}-75^{\circ} \mathrm{W}\right.$ and $\left.30^{\circ} \mathrm{N}-45^{\circ} \mathrm{N}\right)$, c) Europe and the Mediterranean Sea $\left(10^{\circ} \mathrm{W}-36^{\circ} \mathrm{E}\right.$ and $\left.30^{\circ} \mathrm{N}-55^{\circ} \mathrm{N}\right)$, and d) eastern Asia $\left(100^{\circ} \mathrm{E}-120^{\circ} \mathrm{E}\right.$ and $\left.10^{\circ} \mathrm{N}-40^{\circ} \mathrm{N}\right)$, following the RCP6.0 (blue) and RCP8.5 (red) emission scenarios. Relative changes with respect to present-day (normalized to $\mathrm{O}_{3}$ levels) are shown for the "cliVSL" (solid), "obsVSL" (dashed), "cli+bioVSL" (dotted), and "fixVSL" (light) simulations. Near-surface $\mathrm{O}_{3}$ refers to the average of the four lowermost model layers (i.e. first kilometer). Time-series, normalized through the origin, are smoothed applying lowess filtering ( 0.2 fraction). 

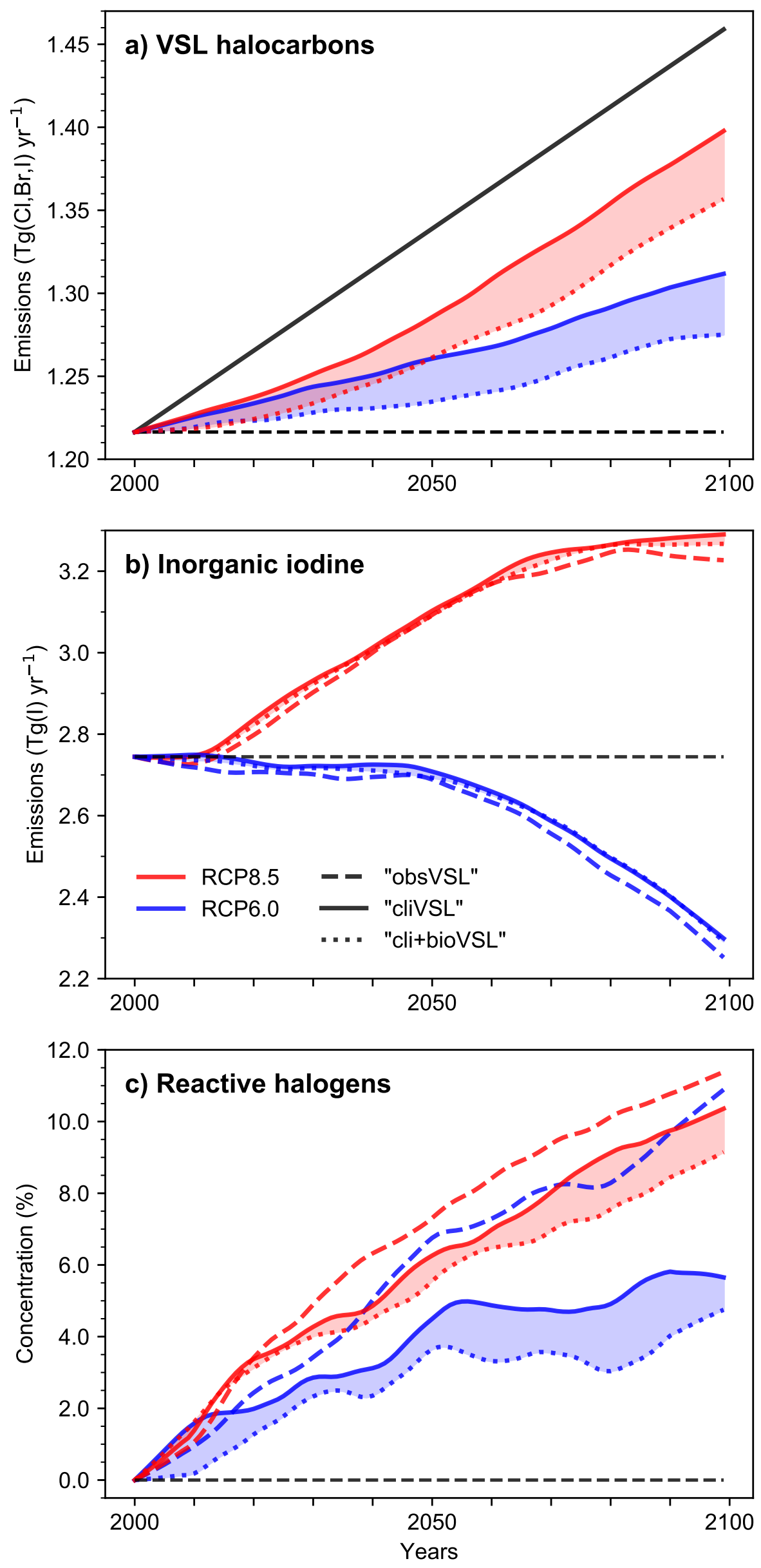


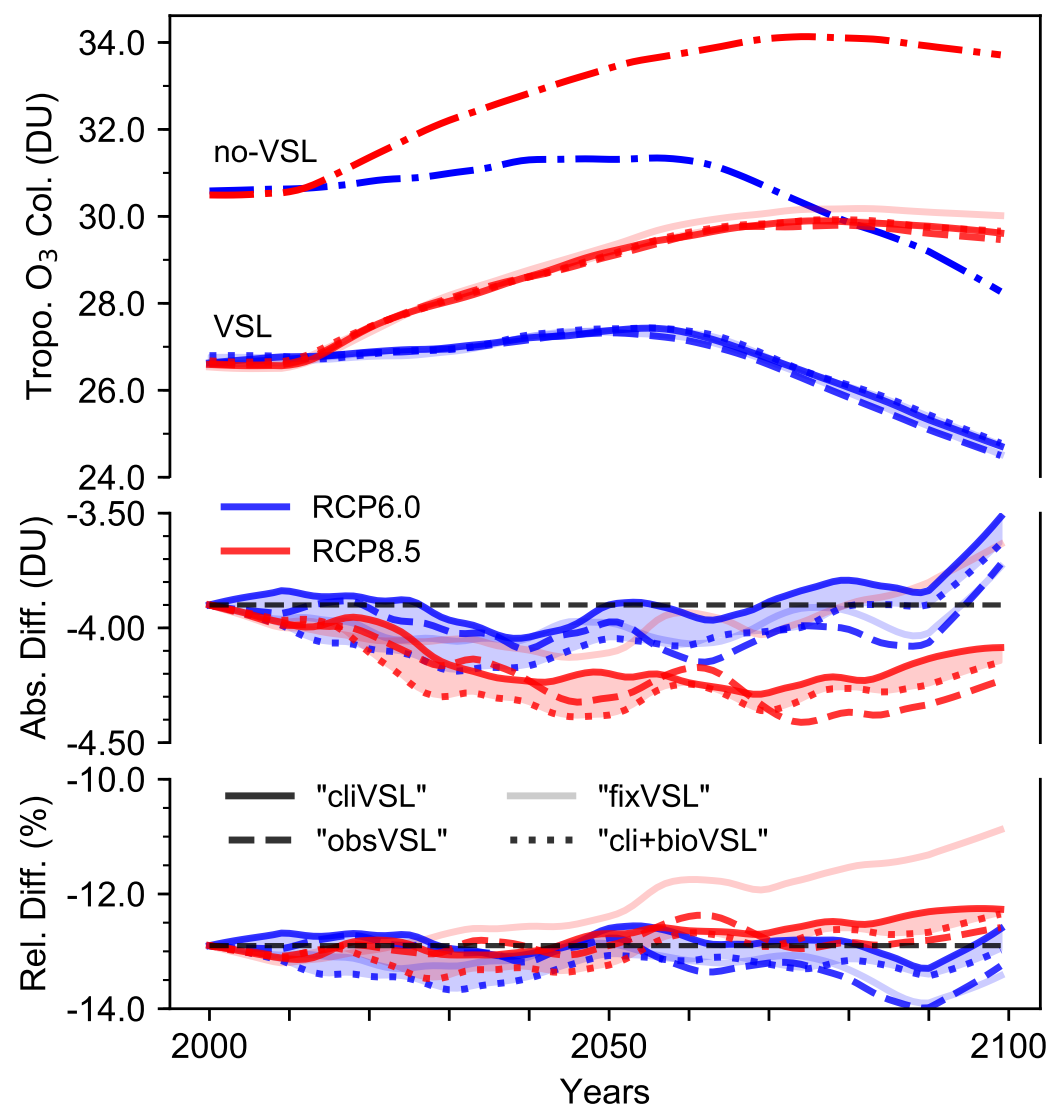



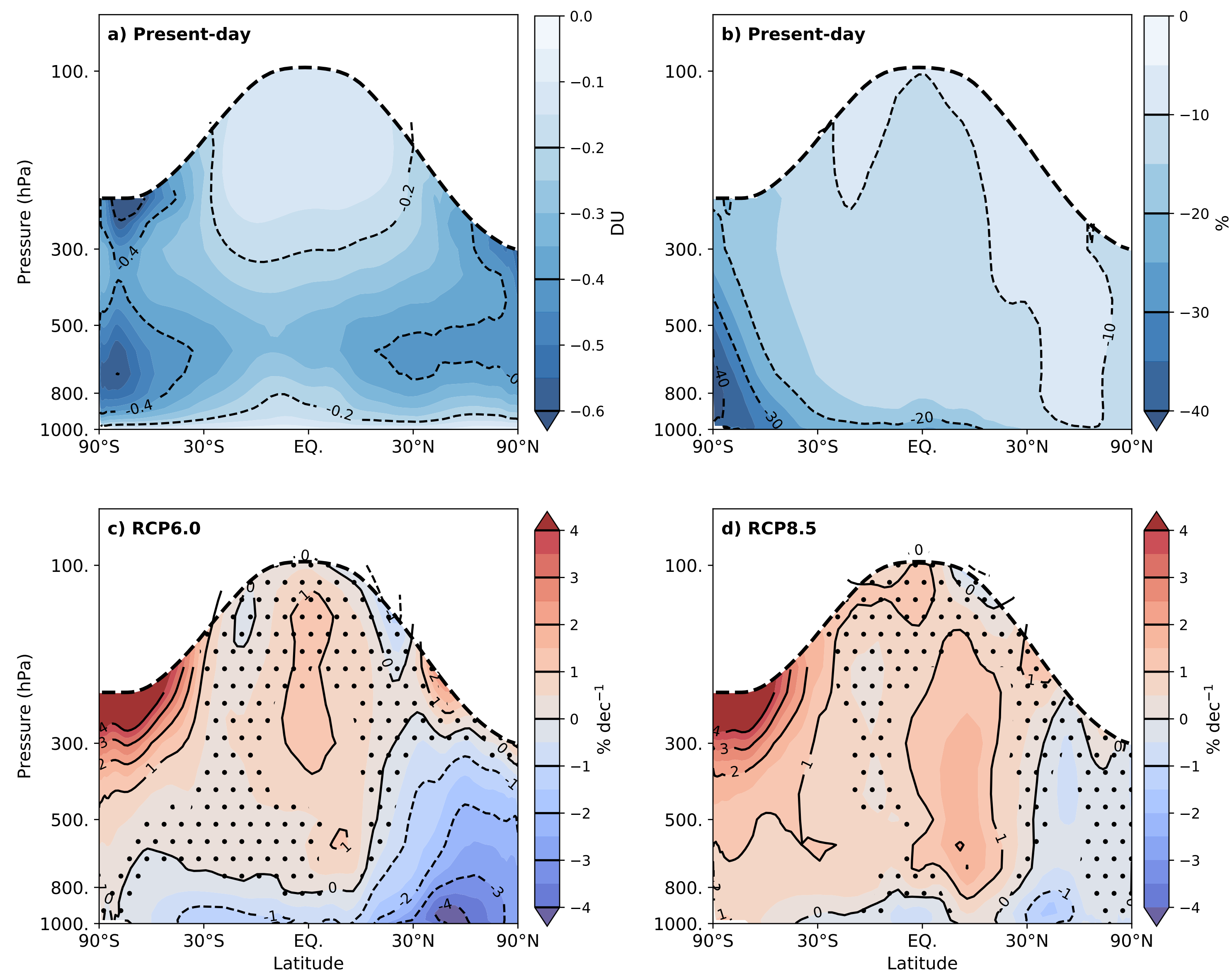

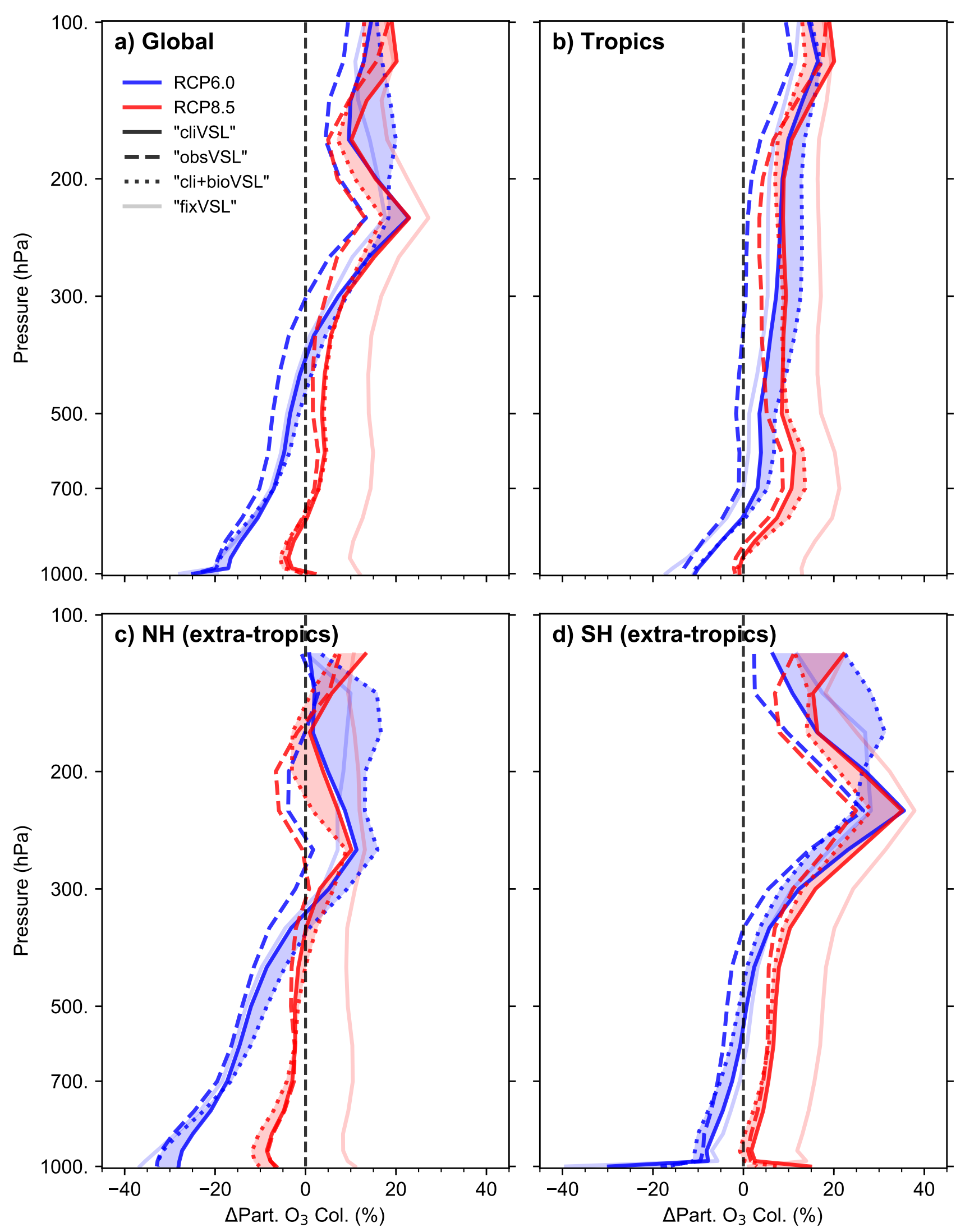

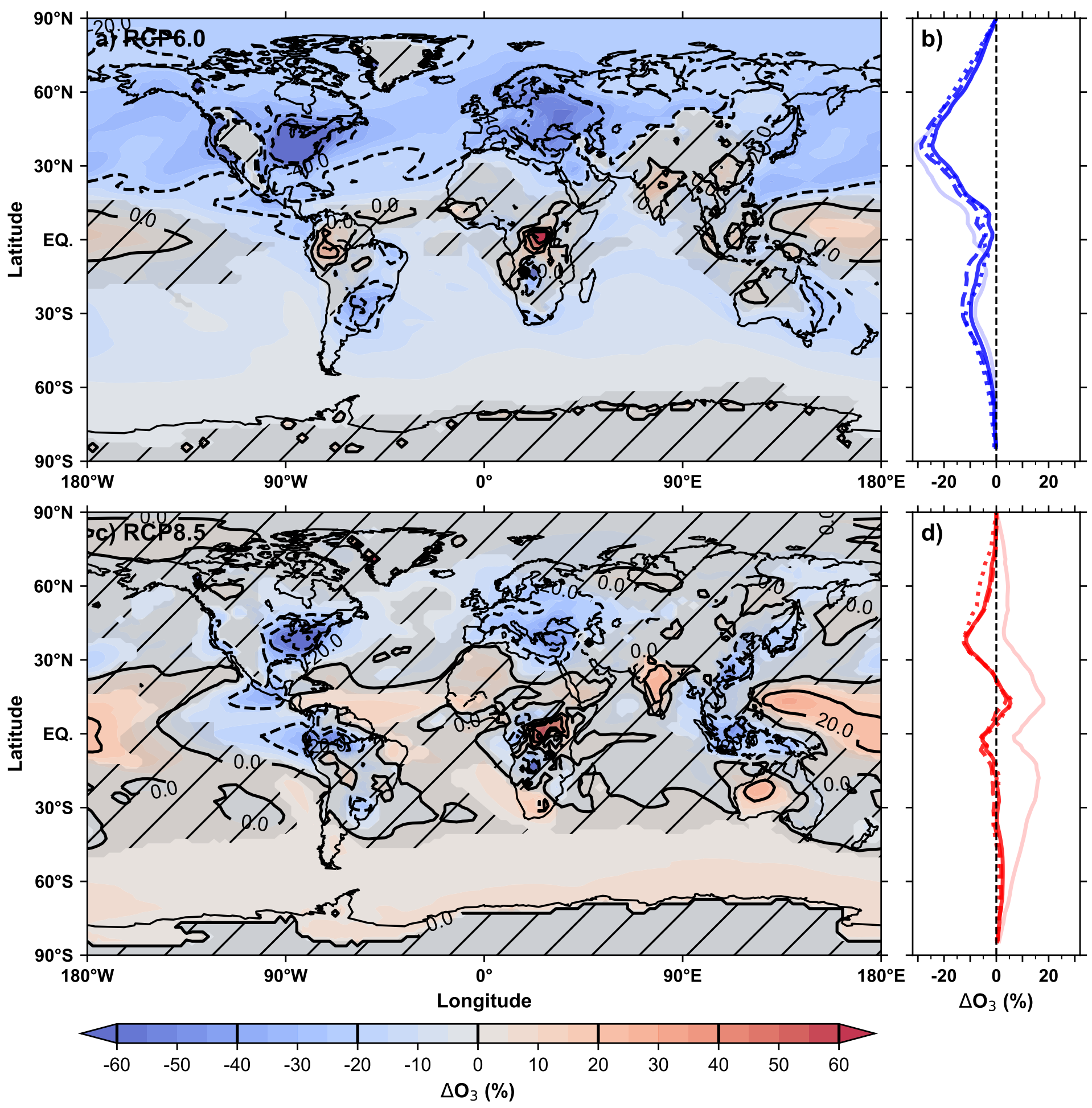


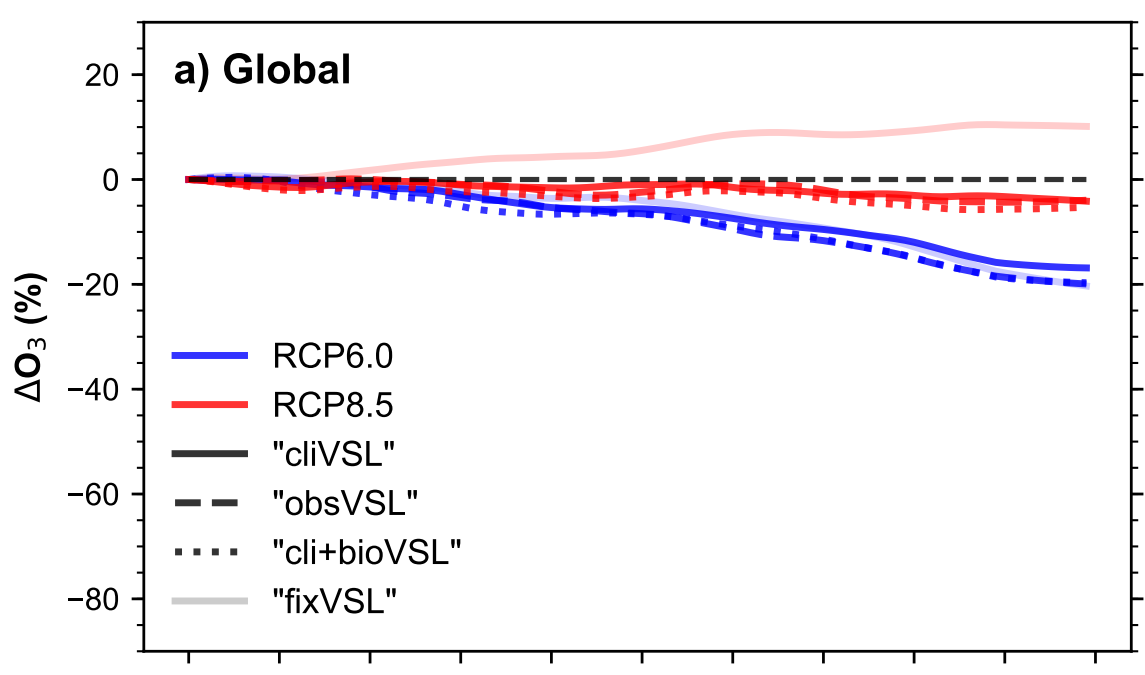

\section{b) Eastern United States}
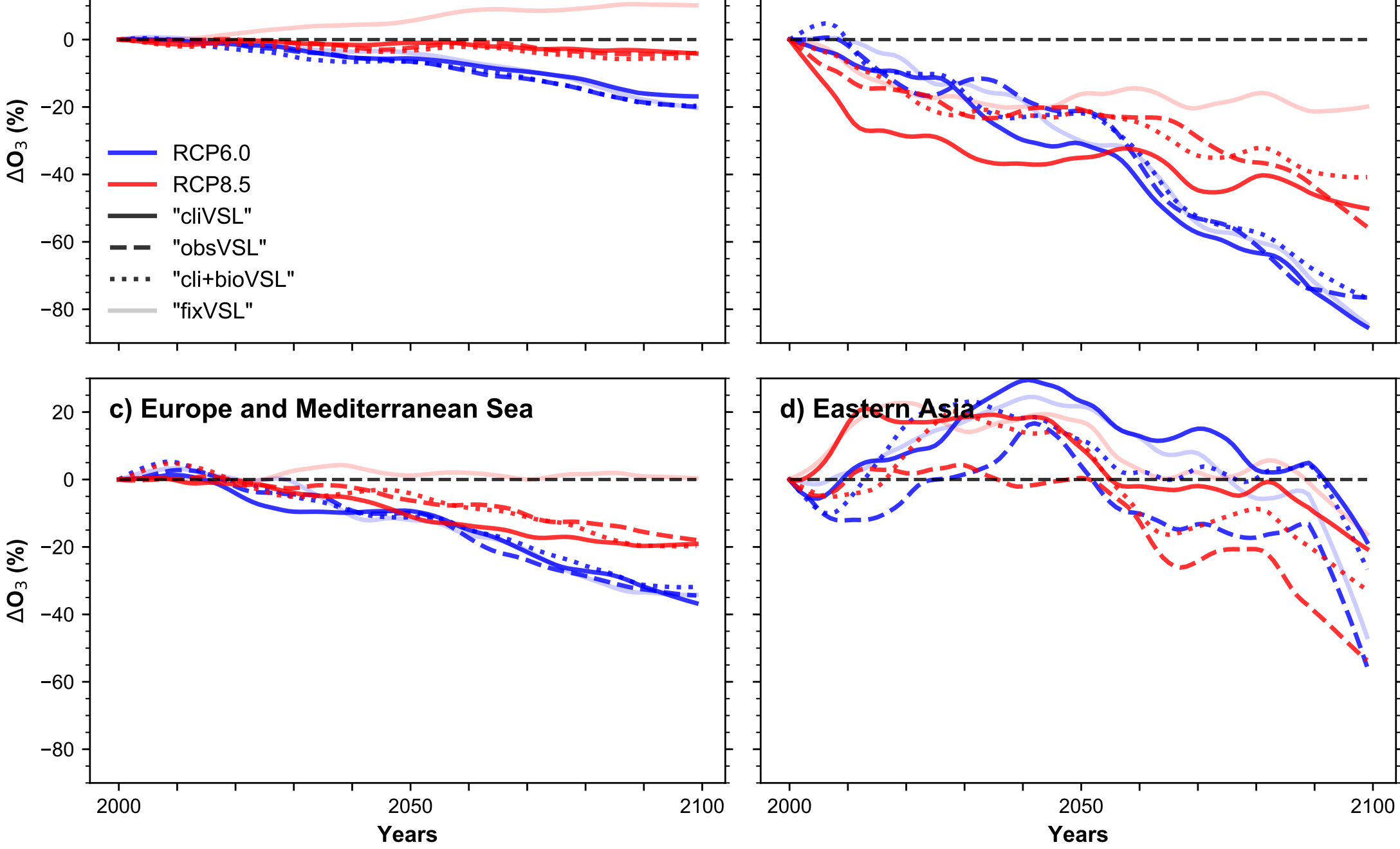